\title{
Optimizing the dosing regimen of linezolid in critically ill septic patients undergoing continuous hemodiafiltration using a pharmacokinetic/ pharmacodynamic analysis and monte carlo simulation
}

\author{
H Barrasa González ${ }^{1 *}$, A Martín López , A Isla Ruiz², A Rodríguez Gascón², A Soraluce Olañeta², E Asín Prieto², \\ A Canut Blasco ${ }^{1}$, JA Sánchez Izquierdo ${ }^{3}$, B Fernández Miret ${ }^{1}$, A Vallejo De la Cueva ${ }^{1}$, FJ Maynar Moliner ${ }^{1}$
}

From ESICM LIVES 2015

Berlin, Germany. 3-7 October 2015

\section{Introduction}

Pharmacokinetic (PK) of drugs in critically ill patients could vary from the general population. Patients undergoing hemodiafiltration (HDF) could present lower linezolid (LZ) concentration than expected. The pharmacokinetic/pharmacodynamic analysis (PK/ PD) is a useful tool to optimize dosing regimens of antibiotic therapy.

\section{Objectives}

To evaluate the efficacy and safety of LZ for the treatment of infections caused by gram-positive microorganisms (GPM) in the Intensive Care Unit (ICU) patients undergoing HDF using a PK/PD analysis and Monte Carlo simulation (MCS).

\section{Methods}

Study developed in three tertiary hospitals in patients with severe sepsis, HDF and treatment with LZ $(600 \mathrm{mg}$ q12h). 8 each patient blood (prefilter and postfilter) and ultrafiltrate samples were taken. Concentrations of linezolid were determined by HPLC-UV. PK analysis and MCS were performed using Phoenix WinNonlin Version 6.3 (Pharsight) and Oracle Crystal Ball programs to assess the probability of successful treatment (PST) [area under the curve (AUC24)/MIC> 100 for different MICs], the probability of $\mathrm{C}_{\min }>2 \mathrm{mg} / \mathrm{L}$ and the risk of

Osakidetza, Vitoria, Spain

Full list of author information is available at the end of the article overexposure (RO) $\left[\mathrm{C}_{\min }>10 \mathrm{mg} / \mathrm{L}\right.$ and/or AUC24> $\left.400 \mathrm{mg}{ }^{*} \mathrm{~h} / \mathrm{L}\right]$ at doses of $600 \mathrm{mg} \mathrm{q} 12$ and q8h. Patients were grouped by liver and renal function considering impaired liver function (ILF) the elevation $>2$ times transaminase and/or elevated bilirubin and severe renal dysfunction (SRD) the presence of $\mathrm{CrCl}<15 \mathrm{ml} / \mathrm{min}$. Group (G) 0: both normal, G1: ILF or SRD, G2: both. Quantitative variables were expressed as mean and standard deviation (SD), qualitative as percentages. $\alpha$ significance level of 0,05 .

\section{Results}

26 patients were included. The AUC $24(\mathrm{mg} * \mathrm{~h} / \mathrm{L})$ was: G0 111 (SD 39), G1 155 (SD 79) and G2 246 (SD64), the $\mathrm{C}_{\min }(\mathrm{mg} / \mathrm{L})$ was: G0 1,5 (SD 1,2), G1 2,5 (SD 1,8) and G2 4,6 (SD 2) and the clearance $(\mathrm{Cl})(\mathrm{L} / \mathrm{h})$ was: G0 12 (SD 4), G1 10,1 (SD 5,9) and G2 8,9 (SD $5,1)$. The PST was $96,81,38$ and $0 \%$ for GPM with MICs of $0,5,1,2$ and $4 \mathrm{mg} / \mathrm{L}$. In the MCS, $600 \mathrm{mg}$ $12 \mathrm{qh}$ ensures $\mathrm{PST}>80 \%$ for $\mathrm{MIC} \leq 1 \mathrm{mg} / \mathrm{L}$ in the presence of some dysfunction (G1 and G2), increasing to> $90 \%$ for all groups with $600 \mathrm{mg}$ q8h without RO. In the G2, the current dose assures PST $>70 \%$ for MIC of 2 , increasing to $>90 \%$ with $600 \mathrm{mg}$ q $8 \mathrm{~h}$ but with high RO (> 30\%). No amount is effective for MIC $\geq 4 \mathrm{mg} / \mathrm{L}$. The probability of $\mathrm{C}_{\min }>2 \mathrm{mg} / \mathrm{L}$ was 23,33 and $85 \%$ for G0, G1 and G2 respectively, increasing to $60 \%$ in G0 and G1 with $600 \mathrm{mg}$ q8h (see summary table in Figure 1). 


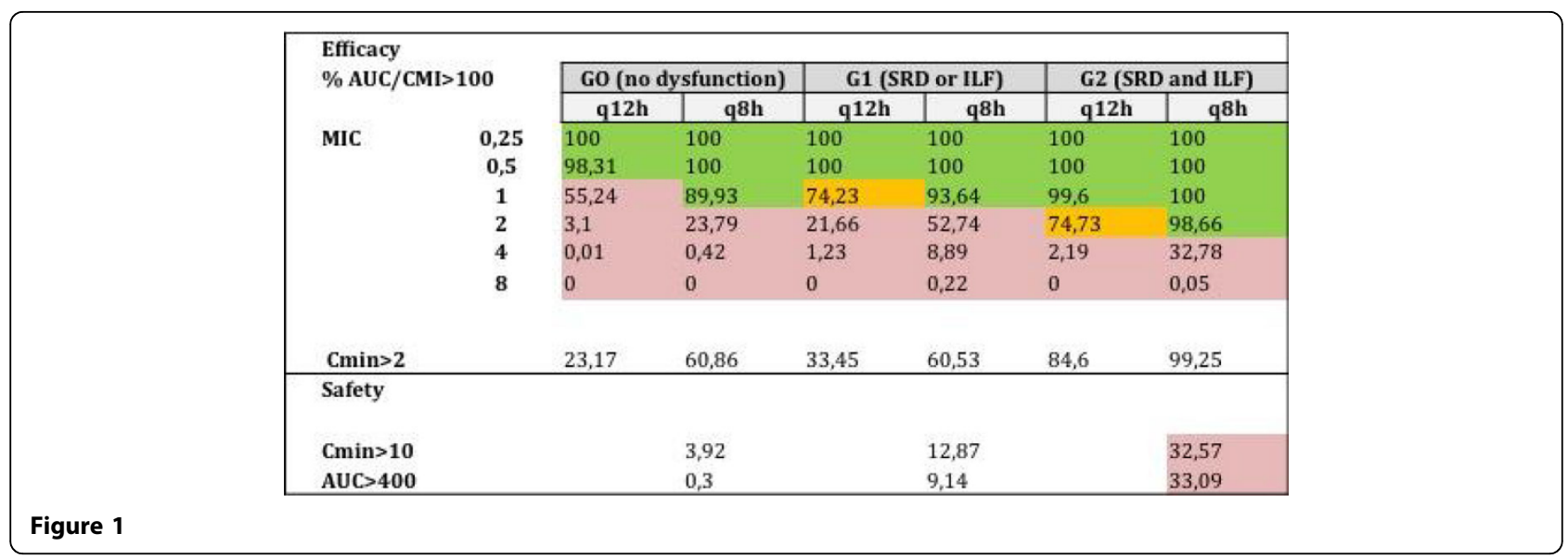

\section{Conclusions}

In patients with RRT, $600 \mathrm{mg}$ q12h guarantees PST $>80 \%$ for $\mathrm{MIC} \leq 1$ in the presence of SRD and/or ILF. For this $\mathrm{MIC}, 600 \mathrm{mg}$ q8h guarantees high PST in all patients and increases the probability of $\mathrm{Cmin}>2$. For MGP with MIC of 2 , only in the presence of both dysfunctions is possible achieving the PK/PD target.

\section{Grant Acknowledgment}

Pfizer sponsored this study.

\section{Authors' details}

'Osakidetza, Vitoria, Spain. ${ }^{2}$ University of the Basque Country, Vitoria, Spain. ${ }^{3}$ Doce de Octubre Hospital, Madrid, Spain.

Published: 1 October 2015

\section{Submit your manuscript to a SpringerOpen ${ }^{\mathcal{O}}$ journal and benefit from:}

- Convenient online submission

- Rigorous peer review

- Immediate publication on acceptance

- Open access: articles freely available online

- High visibility within the field

- Retaining the copyright to your article

Submit your next manuscript at $>$ springeropen.com 